\title{
Hyperresponse in calcium-induced insulin release from electrically permeabilized pancreatic islets of diabetic GK rats and its defective augmentation by glucose
}

\author{
Y. Okamoto ${ }^{1}$, H. Ishida ${ }^{1}$, Y. Tsuura ${ }^{1}$, K. Yasuda ${ }^{1}$, S. Kato ${ }^{1}$, H. Matsubara ${ }^{1}$, M. Nishimura ${ }^{1}$, N. Mizuno ${ }^{1}$, H. Ikeda ${ }^{2}$, \\ Y. Seino ${ }^{1}$ \\ ${ }^{1}$ Department of Metabolism and Clinical Nutrition, Kyoto University Faculty of Medicine, Kyoto, Japan \\ ${ }^{2}$ Pharmaceutical Research Laboratories-II, Takeda Chemical Industry Ltd., Osaka, Japan
}

Summary In spontaneously diabetic GK rats, insulin secretion from pancreatic beta cells in response to glucose is selectively impaired, probably due to deficient intracellular metabolism of glucose and impaired closure of $\mathrm{K}_{\mathrm{ATP}}$ channels during glucose stimulation. By using electrically permeabilized islets of GK rats, we explored the functional modulations in exocytotic steps distal to the rise in $\left[\mathrm{Ca}^{2+}\right] \mathrm{i}$ in the diabetic condition. At $30 \mathrm{nmol} / \mathrm{l} \mathrm{Ca}^{2+}$ (basal conditions) insulin release was similar between GK and non-diabetic control Wistar rats. In response to $3.0 \mu \mathrm{mol} / 1$ $\mathrm{Ca}^{2+}$ (maximum stimulatory conditions), insulin release was significantly augmented in permeabilized GK islets $(p<0.01)$. Raising glucose concentrations from 2.8 to $16.7 \mathrm{mmol} / 1$ further augmented insulin release induced by $3.0 \mu \mathrm{mol} / 1 \mathrm{Ca}^{2+}$ from permeabilized control islets $(p<0.001)$, but had no effect on that from permeabilized GK islets. The stimulatory effect of glucose on insulin release from permeabilized control islets was partly inhibited by 2,4-dinitrophenol, an inhibitor of mitochondrial oxidative phosphorylation $(p<0.01)$. The hyperresponse to $\mathrm{Ca}^{2+}$ in GK islets may play a physiologically compensatory role on the putative functional impairment both in $\left[\mathrm{Ca}^{2+}\right] \mathrm{i}$ rise and energy state in response to glucose in diabetic $\beta$ cells, and may explain the relative preservation of insulin release induced by non-glucose depolarizing stimuli, such as arginine, from pancreatic islets in non-insulin-dependent diabetes mellitus. [Diabetologia (1995) 38: 772-778]

Key words Insulin release, intracellular calcium, exocytosis, GK rat, permeabilized islets.
The impairment of glucose-induced insulin secretion is known to be one of the major characteristics of non-insulin-dependent diabetes mellitus (NIDDM). Insulin release has been found to be selectively reduced in response to glucose, but not to other secreta-

Received: 17 September 1994 and in revised form: 29 December 1994

Corresponding author: Dr. Y. Okamoto, Department of Metabolism and Clinical Nutrition, Kyoto University Faculty of Medicine, 54 Shogoin Kawahara-cho, Sakyo-ku, Kyoto 606, Japan

Abbreviations: GK rat, Goto-Kakizaki rat; NIDDM, non-insulin-dependent diabetes mellitus; NSZ rats, neonatally streptozotocin-induced diabetic rats; KRBB, Krebs-Ringer bicarbonate buffer; BSA, bovine serum albumin; KA, potassium aspartate buffer; DNP, 2,4 dinitrophenol; CaM kinase, $\mathrm{Ca}^{2+}$-calmodulin-dependent protein kinase. gogues such as arginine, both in humans with NIDDM [1-3] and in animal models such as neonatally streptozotocin-induced diabetic rats (NSZ rats) $[4,5]$.

Recently, the GK rat (Goto-Kakizaki rat) has been reported to be a novel spontaneous non-obese model of NIDDM [6-9]. The rats were developed by repetitive selective inbreeding of Wistar rats with abnormal glucose tolerance. After tens of generations, the diabetic state became stable. Thus, the diabetic aetiology of GK rats is thought to be exclusively genetic, and they show glucose intolerance at 2 weeks of age.

It is well established that a rise in the cytoplasmic $\mathrm{Ca}^{2+}$ concentration $\left(\left[\mathrm{Ca}^{2+}\right] \mathrm{i}\right)$ is essential for insulin secretion from pancreatic beta-cells [10-12]. During glucose stimulation, metabolic fluxes such as production of ATP close ATP-sensitive $\mathrm{K}^{+}$channels $\left(\mathrm{K}_{\mathrm{ATP}}\right.$ 
channels). The resultant membrane depolarization brings about $\mathrm{Ca}^{2+}$ influx through voltage-dependent $\mathrm{Ca}^{2+}$ channels, leading to the rise in $\left[\mathrm{Ca}^{2+}\right] \mathrm{i}$, which eventually activates exocytosis of insulin granules. We have recently reported that the inhibition of $\mathbf{K}_{\mathrm{ATP}}$ channel activity in response to glucose is significantly reduced in diabetic beta-cells of NSZ [13] and GK rats [14], probably due to insufficient ATP production by a deficiency of intracellular glucose metabolism. These findings might suggest that the mechanism of impaired insulin secretion induced by glucose in NIDDM is based on the defective step(s) in insulin secretory machinery proximal to the $\left[\mathrm{Ca}^{2+}\right] \mathrm{i}$ elevation. Accordingly, we have demonstrated that the rise in $\left[\mathrm{Ca}^{2+}\right] \mathrm{i}$ in response to glucose is selectively impaired in beta-cells of diabetic NSZ rats [15], and also reported that pancreatic beta-cells maintained under prolonged hyperglycaemic conditions show deficient glucose-induced $\left[\mathrm{Ca}^{2+}\right] \mathrm{i}$ rise together with the decreased insulin secretory capacity to glucose [16].

On the other hand, the exocytotic process distal to the rise in $\left[\mathrm{Ca}^{2+}\right] \mathrm{i}$ may also be affected in diabetes, and can be explored independently of ionic events by permeabilizing the endocrine cells. The elevation of $\mathrm{Ca}^{2+}$ has been reported to be sufficient to activate exocytosis in the permeabilized insulin-secreting cells [17-20] as well as in other endocrine cells [21-24]. However, functional alterations in the insulin secretory machinery distal to $\left[\mathrm{Ca}^{2+}\right] \mathrm{i}$ elevation in diabetic beta-cells are still to be elucidated. In this study, we have examined the modulation of $\left[\mathrm{Ca}^{2+}\right] \mathrm{i}$-activated exocytotic pathway in the diabetic state using electrically permeabilized pancreatic islets of GK rats.

\section{Materials and methods}

Animals. Male diabetic GK rats were donated by Pharmaceutical Research Laboratories-II (Takeda Chemical Industries Ltd., Osaka, Japan). Male non-diabetic age-matched Wistar rats were used as control animals. The animals were fed ad libitum with a standard pelleted chow and allowed free access to water in an air-conditioned room with a 12-h light/dark cycle until killing. All experiments were carried out with GK and control rats at 7 - to 10 -weeks of age.

Measurement of serum glucose and insulin. Blood was drawn from the left renal vein immediately before isolation of the pancreatic islets of Langerhans under pentobarbital anaesthesia ( $40 \mathrm{mg} / \mathrm{kg}$ body weight). Sera obtained by centrifugation were used for the measurements of glucose and immunoreactive insulin. Serum glucose was measured by the glucose- oxidase method [25]. Immunoreactive insulin was determined by radioimmunoassay using the polyethylene glycol method with rat insulin (Novo Nordisk, Copenhagen, Denmark) as the standard [4].

Measurement of insulin release from intact islets. Islets of Langerhans were isolated from GK and control rats by collagenase digestion as described previously [26]. The islets then were preincubated at $37^{\circ} \mathrm{C}$ for $30 \mathrm{~min}$ in Krebs-Ringer bicarbonate buffer (KRBB)[16] supplemented with $2.8 \mathrm{mmol} / \mathrm{l}$ glucose and $0.2 \%$ bovine serum albumin (BSA). Groups of five islets were then batch-incubated for $60 \mathrm{~min}$ at $37^{\circ} \mathrm{C}$ in $0.4 \mathrm{ml}$ KRBB with test materials. At the end of the incubation period, islets were pelleted by centrifugation $(10,000 \times g, 60 \mathrm{~s})$ and aliquots of the buffer were removed and diluted to one-twentieth for insulin assay.

Measurement of insulin release from permeabilized islets. After the preincubation as described above, the islets were washed twice in cold potassium aspartate buffer (KA buffer) containing $140 \mathrm{mmol} / \mathrm{l}$ potassium aspartate, $7 \mathrm{mmol} / \mathrm{l} \mathrm{MgSO}_{4}$, $5 \mathrm{mmol} / 1$ ATP, $2.8 \mathrm{mmol} / \mathrm{l}$ glucose, $2.5 \mathrm{mmol} / 1 \mathrm{EGTA}$, $30 \mathrm{mmol} / 1 \mathrm{HEPES}, 0.5 \% \mathrm{BSA}$ ( $\mathrm{pH} 7.0$ ), with $\mathrm{CaCl}_{2}$ added to give a $\mathrm{Ca}^{2+}$ concentration of $30 \mathrm{nmol} / \mathrm{l}$. The islets were then permeabilized by high voltage dischage (four exposures each of $450-\mu$ s duration to an electrical field of $4.0 \mathrm{kV} / \mathrm{cm}$ ) in $\mathrm{KA}$ buffer and washed once with the same buffer. Groups of five electrically permeabilized islets were then batch-incubated for $60 \mathrm{~min}$ at $37^{\circ} \mathrm{C}$ in $0.4 \mathrm{ml} \mathrm{KA}$ buffer with various concentrations of $\mathrm{Ca}^{2+}$ (from $30 \mathrm{nmol} / 1$ to $10.0 \mu \mathrm{mol} / 1$ ) and test materials. Aliquots of the buffer were assayed for insulin using the same protocol described above. $\mathrm{Ca}^{2+}$ concentrations in the KA buffer were calculated by using the dissociation constants of Martell and Smith [27]. In some series of experiments, insulin was extracted from groups of five islets with $0.4 \mathrm{ml} 1 \mathrm{~mol} / \mathrm{l}$ acetic acid both before and after the permeabilization procedure and the content was determined by radioimmunoassay [4].

Materials. Potassium aspartate was obtained from Sigma Chemicals Co. (St. Louis, Mo., USA); ATP was obtained from Kohjin Co., Ltd. (Tokyo, Japan); and all other reagents were of analytical grade and were obtained from Nacalai Tesque Inc. (Kyoto, Japan).

Statistical analysis. All results are presented as mean \pm SEM for the indicated number of observations. Data were analysed by Student's $t$-test for unpaired data. Differences were considered significant at $p<0.05$.

\section{Results}

Characteristics of $G K$ and control rats. The in vivo characteristics of diabetic GK and non-diabetic Wistar rats are summarized in Table 1 . The body weight and the serum insulin level were not significantly different between the two groups. The serum glucose concentration in the GK rats was significantly higher $(p<0.001)$ than that of the controls. In each experiment, GK rats stably exhibited higher glucose levels than controls.

Insulin release from intact islets. Figure 1 shows the insulin secretory capacity in response to glucose and arginine. Insulin release in response to 2.8 or $8.3 \mathrm{mmol} / \mathrm{l}$ glucose was not significantly different between GK and control rats. Basal insulin secretion at $2.8 \mathrm{mmol} / 1$ glucose was $0.62 \pm 0.03 \mathrm{ng} \cdot$ islet $^{-1} \cdot 60 \mathrm{~min}^{-1}(n=25)$ in control and $0.53 \pm 0.04 \mathrm{ng} \cdot$ islet $^{-1} \cdot 60 \mathrm{~min}^{-1}$ $(n=24)$ in GK rats. Insulin response to $16.7 \mathrm{mmol} / \mathrm{l}$ glucose was significantly decreased in GK rats 
Table 1. Body weight, serum glucose, and serum insulin of control and GK rats

\begin{tabular}{lcc}
\hline & Control & GK \\
\hline Body weight $(\mathrm{g})$ & $274.7 \pm 6.4$ & $256.6 \pm 8.3$ \\
Serum glucose $(\mathrm{mmol} / \mathrm{l})$ & $10.9 \pm 0.3$ & $21.1 \pm 0.5^{\mathrm{a}}$ \\
Serum insulin $(\mathrm{ng} / \mathrm{ml})$ & $2.28 \pm 0.24$ & $2.49 \pm 0.30$ \\
\hline
\end{tabular}

Values are means \pm SEM for 39 control and $43 \mathrm{GK}$ rats.

All animals were in the fed state. ${ }^{a} p<0.001$ vs control

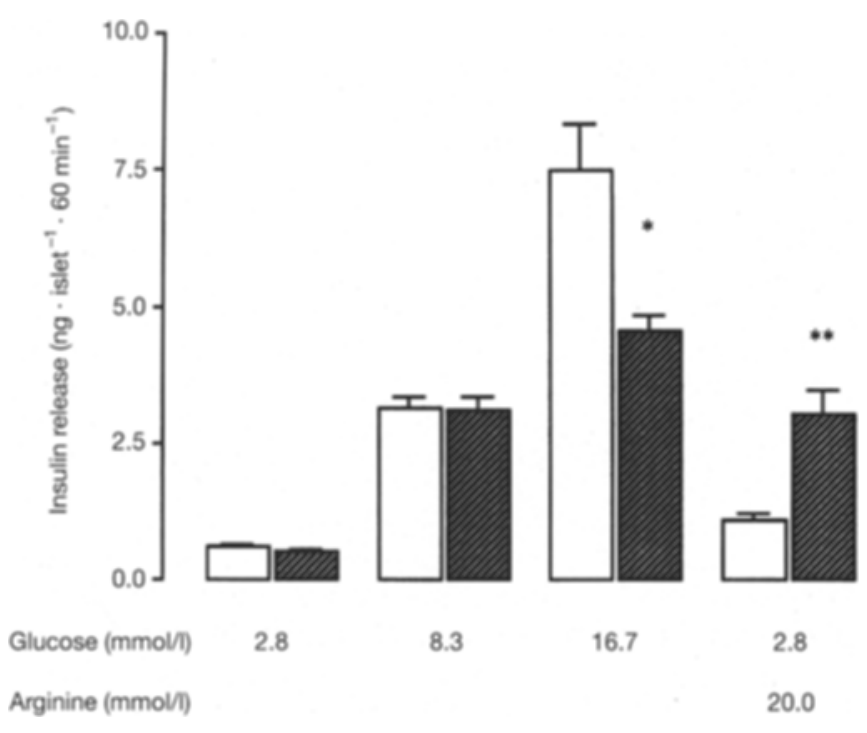

Fig. 1 Effects of glucose and arginine on insulin release from isolated pancreatic islets of control $(\square)$ and GK rats (署). The response was tested for $60 \mathrm{~min}$ at $37^{\circ} \mathrm{C}$ in $\mathrm{KRBB}$ under the indicated conditions. Bars represent mean \pm SEM for $15-25$ batches of islets from three separate experiments. $* p<0.01$, ${ }^{* *} p<0.001$ vs control

(4.52 $\pm 0.30 \mathrm{ng} \cdot$ islet $\left.^{-1} \cdot 60 \mathrm{~min}^{-1}, n=23, p<0.01\right)$ compared with controls $(7.48 \pm 0.85, n=23)$. The rise in glucose concentration from 8.3 to $16.7 \mathrm{mmol} / 1$ in the incubation medium did not elicit further insulin secretion from islets of GK rats. In contrast, $20 \mathrm{mmol} / \mathrm{l}$ arginine in the presence of $2.8 \mathrm{mmol} / \mathrm{lglu}$ cose markedly enhanced insulin release from islets of GK rats $\left(3.02 \pm 0.43 \mathrm{ng} \cdot\right.$ islet $^{-1} \cdot 60 \mathrm{~min}^{-1}, n=15$, $p<0.001)$ compared with that of controls $(1.09 \pm$ $0.10, n=14)$. In another series of experiments, the effect of depolarizing concentrations of potassium was tested. In the presence of $2.8 \mathrm{mmol} / \mathrm{l}$ glucose, insulin secretion induced by $25 \mathrm{mmol} / \mathrm{l}$ potassium also was significantly higher in GK rats (by $3.10 \pm 0.28$-fold, $n=8, p<0.05$ ) when compared with controls (by $1.67 \pm 0.28$-fold, $n=8$ ).

Characteristics of the $\mathrm{Ca}^{2+}$-induced insulin release from electrically permeabilized normal pancreatic islets. In permeabilized insulin-secreting cells, the elevation of $\mathrm{Ca}^{2+}$ levels directly stimulates exocytosis of insulin, as has been previously reported [17-20]. When permeabilized islets were incubated in solu-

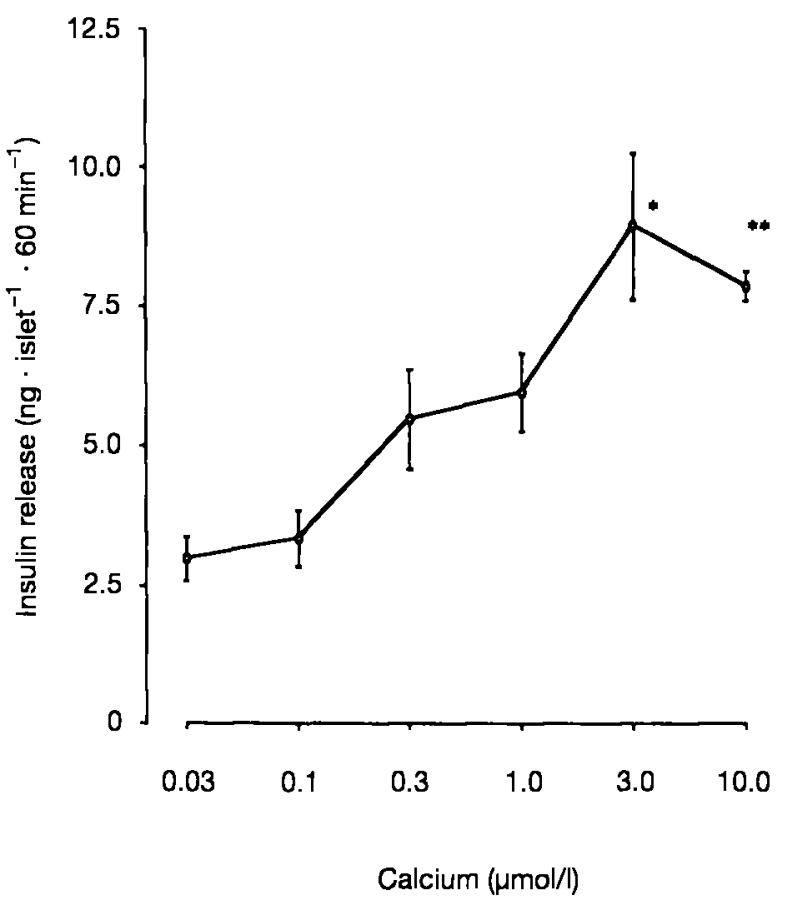

Fig. $2 \mathrm{Ca}^{2+}$-induced insulin release from electrically permeabilized islets. Electrically permeabilized islets obtained from control Wistar rats were incubated for $60 \mathrm{~min}$ in solutions containing $\mathrm{Ca}^{2+}$ in increasing amounts from 0.03 to $10.0 \mu \mathrm{mol} / \mathrm{l}$. Results are means $\pm S E M$ for four batches of islets. ${ }^{*} p<0.05$, ${ }^{* *} p<0.01$ vs the value at $0.03 \mu \mathrm{mol} / 1 \mathrm{Ca}^{2+}$

tions containing increasing $\mathrm{Ca}^{2+}$ concentrations from $30 \mathrm{nmol} / 1$ to $10.0 \mu \mathrm{mol} / \mathrm{l}$, insulin release was dose-dependently stimulated by about three-fold (Fig.2). Secretion was found to be augmented halfmaximally by about $0.5 \mu \mathrm{mol} / 1 \mathrm{Ca}^{2+}$ and maximally by $3.0 \mu \mathrm{mol} / 1 \mathrm{Ca}^{2+}$. The lactate dehydrogenase content of the electrically permeabilized islet was measured as a marker of high molecular weight cytosolic proteins. Compared with the enzyme content in intact islets, that of permeabilized islets was $65.4 \pm 2.6 \%(n=4)$ immediately after electric permeabilization, and $64.5 \pm 2.6 \%(n=4)$ after a 60 min incubation at $30 \mathrm{nmol} / 1 \mathrm{Ca}^{2+}$, indicating that no significant leakage occurred during the incubation period. The staining of islets with trypan blue after the incubation period showed that essentially all of the islet cells were still positive (data not shown), indicating that islets can be kept permeabilized during the incubation period, a finding consistent with results in a previous report [28].

$\mathrm{Ca}^{2+}$ dose-response of insulin release was augmented in electrically permeabilized pancreatic islets of $G K$ rats. Insulin secretory capacity in response to increasing $\mathrm{Ca}^{2+}$ concentrations was compared between electrically permeabilized pancreatic islets of GK and control rats. Although the insulin response to non-stimulatory concentrations of $\mathrm{Ca}^{2+}$ was similar in both groups of islets, the response to stimulatory $\mathrm{Ca}^{2+}$ concentrations was significantly augmented in the 


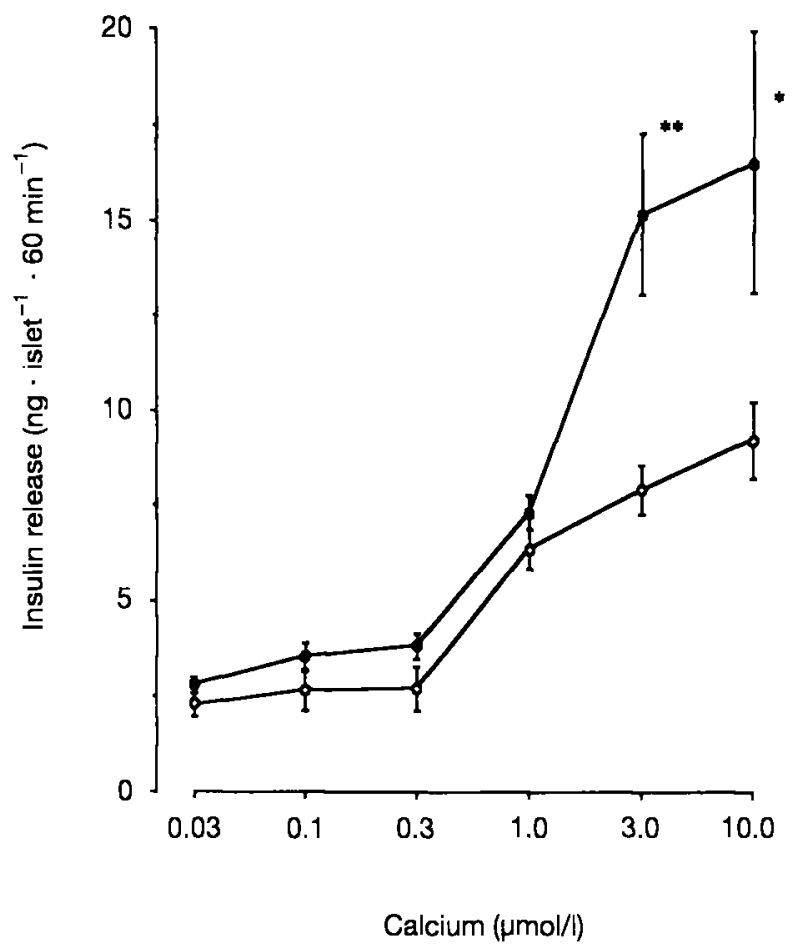

Fig.3 Augmented $\mathrm{Ca}^{2+}$ dose-response of insulin release in electrically permeabilized pancreatic islets of GK rats. Insulin release from electrically permeabilized islets of control $(0)$ and GK rats (O) were tested for $60 \mathrm{~min}$ in solutions containing increasing amounts of $\mathrm{Ca}^{2+}$ from 0.03 to $10.0 \mu \mathrm{mol} / \mathrm{l}$ in the presence of $2.8 \mathrm{mmol} / \mathrm{l}$ glucose. Results are means \pm SEM for 11-12 batches of islets from two separate experiments. ${ }^{*} p<0.05,{ }^{* *} p<0.01$ vs control

Table 2. Effect of glucose on $\mathrm{Ca}^{2+}$-induced insulin secretion from electrically permeabilized control islets

\begin{tabular}{lll}
\hline Agents & \multicolumn{2}{l}{$\mathrm{Ca}^{2+}(\mu \mathrm{mol} / \mathrm{l})$} \\
\cline { 2 - 3 } & 0.03 & 3.0 \\
\hline $2.8 \mathrm{mmol} / 1$ Glucose & $100(22)$ & $100(22)$ \\
$16.7 \mathrm{mmol} / 1$ Glucose & $102 \pm 10(21)$ & $281 \pm 23(22)^{\mathrm{a}}$ \\
$16.7 \mathrm{mmol} / 1$ Glucose + & & \\
$100 \mu \mathrm{mol} / \mathrm{l} 2,4$-dinitrophenol & $95 \pm 9(15)$ & $184 \pm 16(26)^{\mathrm{a}, \mathrm{b}}$ \\
\hline
\end{tabular}

Electrically permeabilized control pancreatic islets were incubated for $60 \mathrm{~min}$ in $\mathrm{KA}$ buffer containing the indicated agents. Data are normalized by taking the secretion at $2.8 \mathrm{mmol} / \mathrm{l}$ glucose as $100 \%$, and expressed as mean $\pm \mathrm{SEM}$. Number of batches from three separate experiments are shown in parentheses. Secretion in the presence of $2.8 \mathrm{mmol} / \mathrm{l}$ glucose was $1.74 \pm 0.26 \mathrm{ng} \cdot$ islet $^{-1} \cdot 60 \mathrm{~min}^{-1}$ at $0.03 \mu \mathrm{mol} / 1$ $\mathrm{Ca}^{2+}$ and $4.99 \pm 0.50 \mathrm{ng} \cdot$ islet $^{-1} \cdot 60 \mathrm{~min}^{-1}$ at $3.0 \mu \mathrm{mol} / 1 \mathrm{Ca}^{2+}$ $(p<0.001)$.

${ }^{\mathrm{a}} p<0.001$ vs $2.8 \mathrm{mmol} / \mathrm{l}$ glucose; ${ }^{\mathrm{b}} p<0.01 \mathrm{vs} 16,7 \mathrm{mmol} / \mathrm{lglu}-$ cose

GK rat islets (Fig. 3). In the presence of $2.8 \mathrm{mmol} / \mathrm{l}$ glucose, insulin response to $30 \mathrm{nmol} / 1 \mathrm{Ca}^{2+}$ was $2.34 \pm 0.36 \mathrm{ng} \cdot$ islet $^{-1} \cdot 60 \mathrm{~min}^{-1}(n=12)$ in control and $2.81 \pm 0.21 \mathrm{ng} \cdot$ islet $^{-1} \cdot 60 \mathrm{~min}^{-1}(n=11)$ in GK rats. At the maximally stimulatory concentration of $3.0 \mu \mathrm{mol} / \mathrm{l} \mathrm{Ca}^{2+}$, however, insulin release was $15.12 \pm 2.12 \mathrm{ng} \cdot$ islet $^{-1} \cdot 60 \mathrm{~min}^{-1}(n=12)$ in GK rats, which was significantly higher than the value of $7.89 \pm 0.66(n=12, p<0.01)$ in control rats. Thus, the increase in $\mathrm{Ca}^{2+}$ concentrations from $30 \mathrm{nmol} / \mathrm{l}$ to $3.0 \mu \mathrm{mol} / 1$ stimulated insulin release by 5.4 -fold in GK rats and by 3.4 -fold in control rats.

Insulin content of intact islets was not statistically different between control $(49.0 \pm 4.3 \mathrm{ng} / \mathrm{islet}, n=15)$ and GK islets ( $52.1 \pm 3.3 \mathrm{ng} /$ islet, $n=15)$. In the case of electrically permeabilized islets, insulin content was also not statistically different between the two groups $(35.6 \pm 2.8 \mathrm{ng}$ /islets, $n=15$ vs $37.3 \pm 3.2$, $n=15$, in control and GK rats, respectively). This indicates that insulin content was as well preserved as with the permeabilization procedure in GK $(71.5 \%)$ and control rats $(72.6 \%)$.

Effect of glucose on $\mathrm{Ca}^{2+}$-induced insulin secretion from electrically permeabilized normal pancreatic islets. The effect of glucose on $\mathrm{Ca}^{2+}$-induced insulin secretion was assessed in electrically permeabilized normal pancreatic islets by raising the glucose concentration in the KA buffer from 2.8 to $16.7 \mathrm{mmol} / \mathrm{l}$. In addition, we examined the effect of 2,4-dinitrophenol (DNP), an inhibitor of mitochondrial oxidative phosphorylation, to explore the underlying mechanism of the glucose effect. In intact control islets incubated in KRBB, insulin release of $8.25 \pm 1.03$ $\mathrm{ng} \cdot$ islet $^{-1} \cdot 60 \mathrm{~min}^{-1}(n=5)$ induced by $16.7 \mathrm{mmol} / 1$ glucose was found to be markedly inhibited by 100 $\mathrm{mol} / 1 \mathrm{DNP}$ to $0.55 \pm 0.14 \mathrm{ng} \cdot$ islet $^{-1} \cdot 60 \mathrm{~min}^{-1}(n=5)$, corresponding to the basal insulin secretion at $2.8 \mathrm{mmol} / \mathrm{l}$ glucose $\left(0.65 \pm 0.09 \mathrm{ng} \cdot\right.$ islet $^{-1} \cdot 60 \mathrm{~min}^{-1}$, $n=5$ ). As shown in Table 2, $16.7 \mathrm{mmol} / 1$ glucose did not enhance the insulin release from electrically permeabilized control islets in the presence of non-stimulatory $30 \mathrm{nmol} / 1 \mathrm{calcium}$. In contrast, $16.7 \mathrm{mmol} / 1$ glucose significantly augmented insulin release in the presence of $3.0 \mu \mathrm{mol} / \mathrm{l}$ calcium $(p<0.001$ vs secretion at $2.8 \mathrm{mmol} / \mathrm{l}$ glucose). DNP at $100 \mu \mathrm{mol} / 1$ significantly suppressed the augmentative effect of $16.7 \mathrm{mmol} / \mathrm{l}$ glucose $(p<0.01)$, but this inhibitory effect on glucose-augmented insulin secretion was only partial; the agent did not completely inhibit the augmented insulin secretion to the secretory level at $2.8 \mathrm{mmol} / \mathrm{l}$ glucose.

It should be noted that the rise in glucose concentration from 2.8 to $16.7 \mathrm{mmol} / \mathrm{l}$ failed to increase the insulin release from intact control pancreatic islets in KA buffer containing $3.0 \mu \mathrm{mol} / 1 \mathrm{Ca}^{2+}(0.23 \pm 0.04$ $\mathrm{ng} \cdot$ islet $^{-1} \cdot 60 \mathrm{~min}^{-1}, n=5$, vs $0.29 \pm 0.05 \mathrm{ng} \cdot$ islet $\left.\mathrm{t}^{-1} \cdot 60 \mathrm{~min}^{-1}, n=5\right)$. This finding excludes the possibility that residual intact beta-cells in electrically permeabilized islets might perturb the secretory data in this experiment.

Impaired glucose augmentation of $\mathrm{Ca}^{2+}$-induced insulin release in electrically permeabilized pancreatic islets of $G K$ rats. The augmentative glucose effect on 


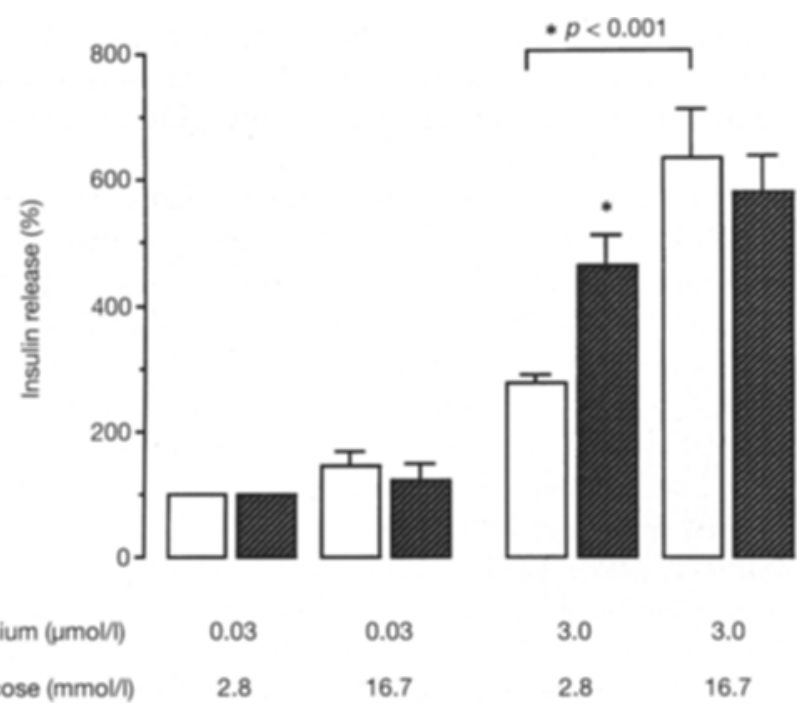

Fig.4 Impairment of glucose effect on $\mathrm{Ca}^{2+}$-induced insulin secretion from electrically permeabilized GK islets. The stimulatory effect of glucose on insulin release from electrically permeabilized islets of control $(\square)$ and GK rats (喓) was tested for $60 \mathrm{~min}$ in KA buffer containing either 0.03 or $3.0 \mu \mathrm{mol} / 1$ $\mathrm{Ca}^{2+}$. Data are normalized by taking the basal insulin secretion at $0.03 \mu \mathrm{mol} / 1 \mathrm{Ca}^{2+}$ in the presence of $2.8 \mathrm{mmol} / 1$ glucose by $100 \%$, and expressed as mean \pm SEM for $15-16$ batches from two separate experiments. ${ }^{*} p<0.001$ vs control

$\mathrm{Ca}^{2+}$-induced insulin release was compared between electrically permeabilized pancreatic islets of control and GK rats (Fig.4). Basal secretion at $30 \mathrm{nmol} / \mathrm{l}$ $\mathrm{Ca}^{2+}$ in the presence of $2.8 \mathrm{mmol} / 1$ glucose was not statistically different between control $(1.97 \pm 0.15$ $\mathrm{ng} \cdot$ islet $\left.^{-1} \cdot 60 \mathrm{~min}^{-1}\right)$ and GK rats $(1.58 \pm 0.16$ $\mathrm{ng} \cdot$ islet $\left.^{-1} \cdot 60 \mathrm{~min}^{-1}\right)$. When the data were normalized by taking the basal secretion in each group as $100 \%$, insulin release induced by $3.0 \mu \mathrm{mol} / \mathrm{l} \mathrm{Ca}^{2+}$ in the presence of $2.8 \mathrm{mmol} / 1$ glucose was significantly higher in GK islets, which again confirms the hyperresponse to $\mathrm{Ca}^{2+}$ in $\mathrm{GK}$ rats. In electrically permeabilized control pancreatic islets, the rise in glucose concentration from 2.8 to $16.7 \mathrm{mmol} / 1$ further augmented insulin release induced by $3.0 \mu \mathrm{mol} / \mathrm{l}$ $\mathrm{Ca}^{2+}(p<0.001)$. In contrast, the rise in glucose concentration had no effect on $\mathrm{Ca}^{2+}$-induced insulin release from electrically permeabilized GK islets.

\section{Discussion}

The GK rat has been shown to be a novel genetic animal model of NIDDM [6-9]. In the present study, the serum glucose level of GK rats was found to be consistently higher than that of control rats. Furthermore, the insulin release induced by glucose in vitro from isolated pancreatic islets of $\mathrm{GK}$ rats was significantly decreased compared with control Wistar rats, whereas the insulin release induced by other secretagogues such as arginine was rather augmented.
These data confirm the previous findings reported both in vivo [7,9] and in vitro $[8,9,29,30]$, indicating a selective reduction of glucose-induced insulin secretion of GK rats. The GK rat thus provides a very suitable model for investigating the pathophysiological aspects of alterations in the insulin secretory machinery of NIDDM beta cells.

A rise in $\left[\mathrm{Ca}^{2+}\right] \mathrm{i}$ is believed to play a crucial role in the regulation of insulin secretion from pancreatic beta-cells in response to various stimuli, including glucose [10-12]. Investigations of permeabilized insulin-secretory cells have shown that the elevation in $\left[\mathrm{Ca}^{2+}\right] \mathrm{i}$ is sufficient to activate exocytosis of insulin granules [17-20]. We have previously reported that the selective impairment of glucose-induced insulin secretion observed in NIDDM beta-cells is associated with the defective $\left[\mathrm{Ca}^{2+}\right] \mathrm{i}$ elevation by glucose, but not by arginine [15], and this phenomenon may be explained in part by defects in the steps proximal to the $\left[\mathrm{Ca}^{2+}\right]$ i elevation in glucose stimulation, including deficient intracellular glucose metabolism [13-15]. However, it is also of great interest to explore the functional modulations in steps distal to the rise in $\left[\mathrm{Ca}^{2+}\right] \mathrm{i}$ in beta cells in the diabetic condition.

It is noteworthy that in this study insulin release in response to stimulatory concentrations of $\mathrm{Ca}^{2+}$ was markedly augmented in electrically permeabilized islets of GK rats. This finding may well explain the hyperresponse of GK rats to depolarizing stimuli, such as arginine, found in this study and previous reports [9], because this positively charged amino acid has been suggested to exert its insulinotropic effect mainly by causing direct depolarization of the plasma membrane, resulting in an increase in $\left[\mathrm{Ca}^{2+}\right] \mathrm{i}$ via $\mathrm{Ca}^{2+}$ influx through the voltage-dependent $\mathrm{Ca}^{2+}$ channels [31].

Portha et al. [9] have reported that the hyperresponse to arginine, together with the decreased insulin release in response to glucose, were partially but not completely improved by perfusion of GK pancreas with buffer containing no glucose. Thus, it can be speculated that the increased insulin response to $\mathrm{Ca}^{2+}$ in electrically permeabilized islets of GK rats may partly be explained by so-called glucose toxicity $[32,33]$, although the involvement of genetic background cannot be excluded. The hyperresponse to arginine at least in the presence of a non-stimulatory concentration of glucose has also been demonstrated in various hyperglycaemic models including NSZ rats $[4,5,34]$, partially pancreatectomized rats [35], in vivo glucose-infused rats [36], and another genetically-diabetic rat model [37]. In the report by Leahy et al. [34], the hyperresponse to arginine in NSZ rats was recovered by $24-\mathrm{h}$ insulin treatment, which again suggests that the increased $\mathrm{Ca}^{2+}$-induced insulin release from permeabilized diabetic islets may be ascribed to prevailing hyperglycaemia. In this re- 
spect, we have preliminarily observed that $\mathrm{Ca}^{2+}$-induced insulin release is similarly augmented in an electrically permeabilized beta cell line, HIT-T 15 cells cultured for $24 \mathrm{~h}$ at high concentrations of glucose (Y. Okamoto and $\mathrm{H}$. Ishida, unpublished observations), whereas the glucose-induced insulin release from the intact cells is found to be blunted as previously demonstrated [38].

The presence of intracellular defects of glucose metabolism has been suggested in beta cells of GK rats $[14,29,30,39]$. Thus, we speculate that the significant enhancement of $\mathrm{Ca}^{2+}$-activated insulin secretion, which was observed in electrically permeabilized islets of GK rats, might play a physiological compensatory role in the putative impairment both in $\left[\mathrm{Ca}^{2+}\right] \mathrm{i}$ rise and energy state after stimulation with glucose in diabetic beta cells. In electrically permeabilized control pancreatic islets, stimulatory concentrations of glucose were found to augment $\mathrm{Ca}^{2+}$. induced insulin release in a dose-dependent manner. This stimulatory effect of glucose on $\mathrm{Ca}^{2+}$-induced insulin release was significantly inhibited by DNP, a metabolic uncoupler which inhibits oxidative phosphorylation. This finding strongly suggests that glucose can augment insulin secretion from electrically permeabilized islets via its intracellular metabolism, even though it is possible that glycolytic enzymes might be lost to some extent during the permeabilization procedure. DNP at $100 \mu \mathrm{mol} / \mathrm{l}$ completely inhibits glucose-induced insulin release from intact pancreatic islets, but its suppression of the stimulatory glucose effect on $\mathrm{Ca}^{2+}$-induced insulin release from electrically permeabilized islets was incomplete. It is, therefore, also suggested that glucose can exert its stimulatory effect through mechanisms other than the generation of ATP. Although the precise mechanisms underlying augmentation by glucose are still to be elucidated, the putative metabolic signals derived from glycolytic intermediates might participate in the stimulatory glucose effect on $\mathrm{Ca}^{2+}$-induced insulin release from electrically permeabilized pancreatic islets. In addition, activation of protein kinases, which facilitate the effect of $\mathrm{Ca}^{2+}$ on the exocytotic pathway, may also play a role.

Using intact pancreatic islets treated with diazoxide and depolarized by potassium, it has been demonstrated that glucose can control the $\mathrm{Ca}^{2+}$-activated exocytotic pathway independently from the ionic events including $\mathbf{K}_{\mathrm{ATP}}$ channels, presumably by activating protein kinases $[40,41]$ or changing energy state [42]. The present finding seems to be consistent with these reports. In permeabilized GK islets, however, glucose failed to enhance the calcium-induced insulin release. This defective augmentation by glucose on the $\mathrm{Ca}^{2+}$-activated effector system could cause the selective impairment of glucose-induced insulin release from intact GK rats in conjunction with the putative impaired elevation and function of intracellular $\mathrm{Ca}^{2+}$ probably due to the disturbed intracellular glucose metabolism after the glucose stimulation [14].

The detailed molecular mechanisms by which $\mathrm{Ca}^{2+}$ acts on exocytosis are still unclear, but studies particularly using chromaffin granules have reported that some cytosolic proteins such as calmodulin and members of the annexin family can bind to secretory granules in a $\mathrm{Ca}^{2+}$-dependent manner $[24,43]$. In secretory granules of pancreatic islets, the presence of $\mathrm{Ca}^{2+}$-calmodulin-dependent protein kinases (CaM kinases) and endogenous substrates have also been demonstrated [44]. Recently, it has been reported that glucose activates $\mathrm{CaM}$ kinase II in pancreatic islets over a similar concentration range to glucose-induced insulin secretion [45]. The precise mechanism of the increased $\mathrm{Ca}^{2+}$ sensitivity at non-stimulatory concentrations of glucose and of the absence of glucose effect to enhance the secretory response to $\left[\mathrm{Ca}^{2+}\right] \mathrm{i}$ elevation in diabetic beta cells is still under investigation, but it is possible that the phosphorylation state of exocytosis-related $\mathrm{Ca}^{2+}$-dependent proteins might be altered through putative metabolic abnormalities under prolonged hyperglycaemic conditions. The further clarification of abnormal regulatory systems in intracellular signalling for insulin secretion is necessary to elucidate the underlying mechanism of the selective impairment in glucose-induced insulin secretory capacity characteristic of beta cells in NIDDM.

Acknowledgements. The authors thank Y. Okada and A. Hazama (Department of Cellular and Molecular Physiology, National Institute for Physiological Sciences, Okazaki, Japan) for computing free $\mathrm{Ca}^{2+}$ in the presence of EGTA, and Ms. P.J. Kaisaki for useful discussion. This study was supported by a Grant-in-Aid for scientific research from the Ministry of Education, Science and Culture; the Committee of Experimental Models of Intractable Diseases of the Ministry of Health and Welfare of Japan; a grant provided the Ichiro Kanehara Foundation and the Japan Diabetes Foundation; by a grant for diabetes research from Otsuka Pharmaceutical Co., Ltd. (Tokyo, Japan).

\section{References}

1. Pfeiffer MA, Halter JB, Porte D Jr (1981) Insulin secretion in diabetes mellitus. Am J Med 70: 579-588

2. Ward WK, Beard JC, Halter JB, Pfeiffer MA, Porte D (1984) Pathophysiology of insulin secretion in non-insulindependent diabetes mellitus. Diabetes Care 7: 491-502

3. Leahy JL (1990) Natural history of $\beta$-cell dysfunction in NIDDM. Diabetes Care 13: 992-1010

4. Tsuji K, Taminato T, Usami M et al. (1988) Characteristic features of insulin secretion in the streptozotocin-induced NIDDM rat model. Metabolism 37: 1040-1044

5. Giroix MH, Portha B, Kergoat M, Bailbe D, Picon L (1983) Glucose insensitivity and amino-acid hypersensitivity of insulin release in rats with non-insulin-dependent diabetes. Diabetes 32: 445-451 
6. Goto Y, Kakizaki M, Masaki N (1975) Spontaneous diabetes produced by selective breeding of normal Wistar rats. Proc Jpn Acad 51: 80-85

7. Goto Y, Kakizaki M (1981) The spontaneous-diabetes rat: a model of noninsulin dependent diabetes mellitus. Proc Jpn Acad 57: 381-384

8. Kimura K, Toyota T, Kakizaki M, Kudo M, Takebe K, Goto $Y$ (1982) Impaired insulin secretion in the spontaneous diabetic rat. Tohoku J Exp Med 137: 453-459

9. Portha B, Serradas P, Bailbe D, Suzuki K, Goto Y, Giroix MH (1991) $\beta$-cell insensitivity to glucose in the GK rat, a spontaneous nonobese model for type 2 diabetes. Diabetes 40: $486-491$

10. Wollheim CB, Biden TJ (1986) Signal transduction in insulin secretion: comparison between fuel stimuli and receptor agonists. Ann NY Acad Sci 488: 1043-1052

11. Prentki M, Matschinsky FM (1987) $\mathrm{Ca}^{2+}$, cAMP, and phospholipid-derived messengers in coupling mechanisms of insulin secretion. Physiol Rev 67: 1185-1248

12. Rajan AS, Aguilar-Bryan L, Nelson DA et al. (1990) Ion channels and insulin secretion. Diabetes Care 13: 340-363

13. Tsuura $Y$, Ishida $H, O$ okamoto $Y$ et al. (1992) Impaired glucose sensitivity of ATP-sensitive $\mathrm{K}^{+}$channels in pancreatic $\beta$ cells in streptozotocin-induced NIDDM rats. Diabetes 41: 861-865

14. Tsuura Y, Ishida H, Okamoto Yet al. (1993) Glucose sensitivity of ATP-sensitive $\mathrm{K}^{+}$channels is impaired in $\beta$ cells of the GK rat, a new genetic model of NIDDM. Diabetes 42: 1446-1453

15. Tsuji K, Taminato T, Ishida H, Okamoto Yet al. (1993) Selective impairment of the cytoplasmic $\mathrm{Ca}^{2+}$ response to glucose in rat pancreatic $\beta$-cells of streptozotocin-induced noninsulin-dependent diabetic rats. Metabolism 42: 1424-1428

16. Okamoto Y, Ishida H, Taminato T et al. (1992) Role of cytosolic $\mathrm{Ca}^{2+}$ in impaired sensitivity to glucose of rat pancreatic islets exposed to high glucose in vitro. Diabetes 41: $1555-1561$

17. Pace CS, Tarvin JH, Neighbors AS, Pirkle JA, Greider MH (1980) Use of a high voltage technique to determine the molecular requirements for exocytosis in islet cells. Diabetes 29: 911-918

18. Yaseen MA, Pedley KC, Howell SL (1982) Regulation of insulin secretion from islets of Langerhans rendered permeable by electric discharge. Biochem J 206: 81-87

19. Jones PM, Persaud SJ, Howell SL (1989) Time-course of $\mathrm{Ca}^{2+}$-induced insulin secretion from perifused, electrically permeabilized islets of Langerhans: effects of cAMP and a phorbol ester. Biochem Biophys Res Commun 162: 9981003

20. Ullrich S, Prentki M, Wollheim CB (1990) Somatostatin inhibition of $\mathrm{Ca}^{2+}$-induced insulin secretion in permeabilized HIT-T15 cells. Biochem J 270: 273-276

21. Ronning SA, Martin TFJ (1986) Characterization of $\mathrm{Ca}^{2+}$ stimulated secretion in permeable $\mathrm{GH} 3$ pituitary cells. J Biol Chem 261: 7834-7839

22. Oetting M, LeBoff MS, Levy S et al. (1987) Permeabilization reveals classical stimulus-secretion coupling in bovine parathyroid cells. Endocrinology 121: 1571-1576

23. Guild S, Frey EA, Pocotte SL, Kebabian JW (1988) Adenosine 3', 5'-cyclic monophosphate-mediated enhancement of calcium-evoked prolactin release from electrically permeabilized 7315c tumour cells. Br J Pharmacol 94: 737-744

24. Burgoyne RD (1991) Control of exocytosis in adrenal chromaffin cells. Biochim Biophys Acta 1071: 174-202

25. Marks V, Lloyd K (1963) Preservation of blood sample for glucose analysis by glucose oxidase. Clin Chem Acta 8: 326
26. Sutton R, Peters M, Mcshane P, Gray DWR, Morris $P$ (1986) Isolation of rat pancreatic islets by ductal injection of collagenase. Transplantation (Baltimore) 42: 689-691

27. Martell AE, Smith RM (1974) Critical stability constants: amino acids (vol 1). Plenum Press, New York, p 269

28. Jones PM, Persaud SJ, Howell SL (1992) $\mathrm{Ca}^{2+}$-induced insulin secretion from electrically permeabilized islets. Biochem J 285: 973-978

29. Giroix M-H, Vesco L, Portha B (1993) Functional and metabolic perturbations in isolated pancreatic islets from the GK rat, a genetic model of noninsulin-dependent diabetes. Endocrinology 132: 815-822

30. Östenson C-G, Khan A, Abdel-Halim SM, Guenifi A, Suzuki K, Goto Y, Efendic S (1993) Abnormal insulin secretion and glucose metabolism in pancreatic islets from the spontaneously diabetic GK rat. Diabetologia 36: 3-8

31. Blachier F, Mourtada A, Sener A, Malaisse WJ (1989) Stimulus-secretion coupling of arginine-induced insulin release: uptake of metabolized and nonmetabolized cationic amino acids by pancreatic islets. Endocrinology 124: 134141

32. Rossetti L, Giaccari A, DeFronzo RA (1990) Glucose toxicity. Diabetes Care 13: 610-630

33. Leahy JL, Bonner-Weir S, Weir GC (1992) $\beta$-cell dysfunction induced by chronic hyperglycaemia. Diabetes Care 15: $442-455$

34. Leahy JL, Bonner-Weir S, Weir GC (1985) Abnormal insulin secretion in a streptozocin model of diabetes. Effects of insulin treatment. Diabetes 34: 660-666

35. Rossetti L, Gerald IS, Zawalich W, DeFronzo RA (1987) Effect of chronic hyperglycaemia on in vivo insulin secretion in partially pancreatectomized rats. J Clin Invest 80:1037-1044

36. Leahy JL, Cooper HE, Weir GC (1987) Impaired insulin secretion associated with near normoglycemia. Study in normal rats with 96-h in vivo glucose infusions. Diabetes 36: $459-464$

37. Voyles N R, Powell AM, Timmers KI et al. (1988) Reversible impairment of glucose-induced insulin secretion in SHR/N-cp rats. Diabetes 37: 398-404

38. Inagaki N, Yasuda K, Inoue G, Okamoto Y et al. (1992) Glucose as regulator of glucose trasport activity and glucose-transporter mRNA in hamster $\beta$-cell line. Diabetes 41: 592-597

39. Östenson C-G, Abdel-Halim SM, Rasschaert J et al. (1993) Deficient activity of FAD-linked glycerophosphate dehydrogenase in islets of GK rats. Diabetologia 36: 722-726

40. Gembal M, Gilon P, Henquin JC (1992) Evidence that glucose can control insulin release independently from its action on ATP-sensitive $\mathrm{K}^{+}$channels in mouse B cells. J Clin Invest 89: 1288-1295

41. Sato Y, Aizawa T, Komatsu M, Okada N, Yamada T (1992) Dual functional role of membrane depolarization/ $\mathrm{Ca}^{2+}$ influx in rat pancreatic B-cell. Diabetes 41: 438-443

42. Gembal M, Detimary P, Gilon P, Gao ZY, Henquin JC (1993) Mechanisms by which glucose can control insulin release independently from its action on adenosine triphosphate-sensitive $\mathrm{K}^{+}$channels in mouse B cells. J Clin Invest 91: 871-880

43. Burgoyne RD (1990) Secretory vesicle-associated proteins and their role in exocytosis. Annu Rev Physiol 52: 647-659

44. Watkins DT (1991) $\mathrm{Ca}^{2+}$-calmodulin dependent phosphorylation of islet secretory granule proteins. Diabetes 40 : 1063-1068

45. Wenham RM, Landt M, Easom RA (1994) Glucose activates the multifunctional $\mathrm{Ca}^{2+}$ /calmodulin-dependent protein kinase II in isolated rat pancreatic islets. J Biol Chem 269: 4947-4952 